\title{
Factors Affecting Adoption of Introduced Physical Soil and Water Conservation Measures on Cultivated Land in Bahirdar Zuria Woreda, Amhara, Ethiopia
}

\author{
Kefyialew Tilahun Ejegue ${ }^{1} \quad$ Menfes Tadesse Eirgete $^{2}$ \\ 1 Department of Natural Resource Management, College of Agriculture and Natural Resource, Mekdela Amba \\ University, P.O. Box 32, Tulu Awuliya, Ethiopia \\ 2 Wondo Genet Colleges of Forestry and Natural Resources, Hawassa University, Ethiopia
}

\begin{abstract}
Soil degradation attributed to soil erosion is one of the most serious environmental problems in Highlands of Ethopia. However, farmers' adoption of introduced physical soil and water conservation measures and maintenance of existing PSWC measures was limited on cultivated land. This study was aimed at investigating factors affecting the adoption of introduced physical soil and water conservation practices in Bahir Dar Zuria Woreda. Multi-stage sampling techniques were employed to select sample kebeles and representative households. Data were collected from 132 sample households. Descriptive statistics and logistic regression models were used to analyse the data. The descriptive result showed that improved soil bund and cut off drains are relatively dominant conservation structures practiced by smallholder farmers. $64.8 \%$ of the respondents did not maintain the existing soil conservation structures while only $35.2 \%$ were maintained initially adopt soil conservation structures. On the other hand, majority of the smallholder farmers (40\%) and 37\% were perceived medium and high soil erosion problem on their cultivated land. The logistic regression model result showed that the profitability of the structure in erosion control, extension contact, training, and perception of the household head on soil erosion problems was found to be positive and significant at a $1 \%$ level of significance to the adoption of PSWC measure. Membership and off-farm activity were found to influence the adoption of soil conservation structures negatively and significantly. Therefore, to make the use and maintenance of PSWC measure sustainable, due attention on regular follow-up and awareness creation work should be done to enable farmers allocating their time and labour force for maintenance of soil conservation beside to other off farm activities.
\end{abstract}

Keywords: Adoption, Logistic regression, Physical soil and water conservation, Soil erosion, Sustainability

DOI: $10.7176 /$ JEES/11-5-03

Publication date:May $31^{\text {st }} 2021$

\begin{tabular}{|l|l|}
\hline Abbreviations & Full name \\
\hline SWC & Soil and water conservation \\
\hline PSWC & Physical soil and water conservation \\
\hline NGO & Non-governmental organization \\
\hline
\end{tabular}

\section{INTRODUCTION}

Land degradation in the form of soil erosion and nutrient depletion threatens food security and the sustainability of agricultural production in sub-Saharan Africa (Erkossa et al., 2015). About $80 \%$ of agricultural land in the world is suffering from moderate to severe soil erosion (Angima et al., 2003, De Graaff et al., 2009). In Ethiopia, where agriculture is the mainstay of the national economy, its production has been highly dependent on natural resources for centuries (Amsalu et al., 2007). However, increasing pressure due to the increased human population has degraded vital natural resources in the country and became an atrocious threat to sustainable agriculture (Gete and Hurni, 2001, Haregeweyn et al., 2017). Particularly, soil degradation attributed to soil erosion is one of the most serious environmental problems in Highlands of Ethopia (Haregeweyn et al., 2017). In addition, nutrients are lost in agricultural land via soil erosion, crop residue removal, harvested product, and leaching, and gaseous (Kiros et al., 2014, Van Beek et al., 2016, Ejegue, 2021). Low intrinsic soil fertility, negative nutrient balance, limited replenishment of removed nutrients, and high erosion rates cause soil fertility decline to become a major threat to current and future food production (Laekemariam et al., 2016, Ejegue, 2021). Highland areas of Ethiopia are receiving high rainfall and are occupied by high population density are likely to be the major reason for soil erosion in the form of water erosion (Hurni et al., 2010, Haregeweyn et al., 2017). Furthermore, the main cause of soil erosion of Ethiopia highland areas are often due to cultivation of the steep and fragile soils, limited recycling of dung and crop residues and overgrazing (Habtamu et al., 2014); agricultural intensification (Desta, 2010, Adgo et al., 2013,Amare et al., 2013,Adimassu et al.,2014, Haregeweyn et al., 2017). Soil erosion problems also aggravated by a compounded factor like low adoption SWC technology, institutions, demographic, physical factors, and policy issues (Gete et al., 2006). And also some farmers dismantled the conservation structures once built in the past through food for work programs on 
their cultivated land (Bekele and Holden, 1999, Fisum et al., 2002, Yeraswork, 2000).

In response to soil degradation challenges, government, NGO and development partners have invested substantial resources in promoting soil and water conservation practices since the mid-1970s and 80s as part of efforts to improve environmental conditions and ensure sustainable and increased agricultural production (Bekele and Holder, 1999, Menale et al., 2008, Shimelis, 2012). Combating land degradation and investing in the soil and water conservation for future generations is a major development task promoting sustainable land management (Hurni et al., 2010, Ejegue, 2021). Various site-specific studies in Ethiopia indicated implementation of PSWC measures had positive effects including reduction runoff, soil loss, changing interlope gradient, enhancing moisture storage, improving soil quality, and increasing crop productivity (Amdemariam et al., 2011, Admassu et al., 2014, Ademe et al., 2017). In Ethiopia, a hundred and thousand kilometers of fanyajuu, soil/stone bunds, stone-faced soil bund, and hillside terrace were constructed on croplands (Haregeweyn et al., 2012, Kebede, 2014). However, reports indicated that physical soil and water conservation structures have not been sustainably implemented on cultivated land by the smallholder farmers (Fisum et al., 2002, Yeraswork, 2000). These problems resulted in a negative attitude towards the adoption of soil and water conservation structures. Similarly in the study area, there is less willingness to accept and maintain the existing physical soil and water conservation over a reasonably long period of time in their farmland. Besides, soil erosion is a major contributor to the prevailing food insecurity in the area. Therefore, this study aimed to investigate factors affecting the farmers' adoption decision of introduces physical soil and water conservation measure by smallholder farmers on cultivated land.

\section{MATERIALS AND METHODS}

\subsection{Description of the Study Area}

The study was conducted in Bahir Dar Zuria woreda in West Gojam Zone in Amhara Regional State. It is situated on the southern shore of Lake Tana. It is located at $565 \mathrm{~km}$ North West of Addis Ababa, having latitude and longitudinal elevation between $11^{\circ} 25$ 'N- $11^{\circ} 55^{\prime} \mathrm{N}$ and $37^{\circ} 04^{\prime} \mathrm{E}-37^{\circ} 39^{\prime} \mathrm{E}$, respectively, with an average elevation of $1840 \mathrm{~m}$ above sea level. The agro-climatic zone of the study area is Woyna Dega within an average annual temperature of $210 \mathrm{C}$. The annual average rainfall of the study area is between $900 \mathrm{~mm}$ to $1035 \mathrm{~mm}$. The entire area of the study district has a topography characterized by gently sloping to steep slopes, with undulating mountains, rill, and gullies are common features of the study area (Astatike, 2016).This makes the area highly exposed to serious soil erosion problem. The local geology and its interaction with climate determine the nature and type of soil. The major portions of the agricultural soils in the district are shallow this makes the area highly exposed to serious soil erosion problem. And some part of the district, soil is largely light brown and has sandy loam texture with high infiltration rate. The soil types in the study area are Nitisols (red), Vertisols (black) and Vertic Nitisol (Mekonnen, 2015). Agriculture is the dominant sector and biggest employer of the economically active population in the study area (more than $88 \%$ of the total population). The livelihood of the community is dependent on a mixed farming system i.e. crop production and animal rearing is the main economic activity (Fentahun et al., 2007). 


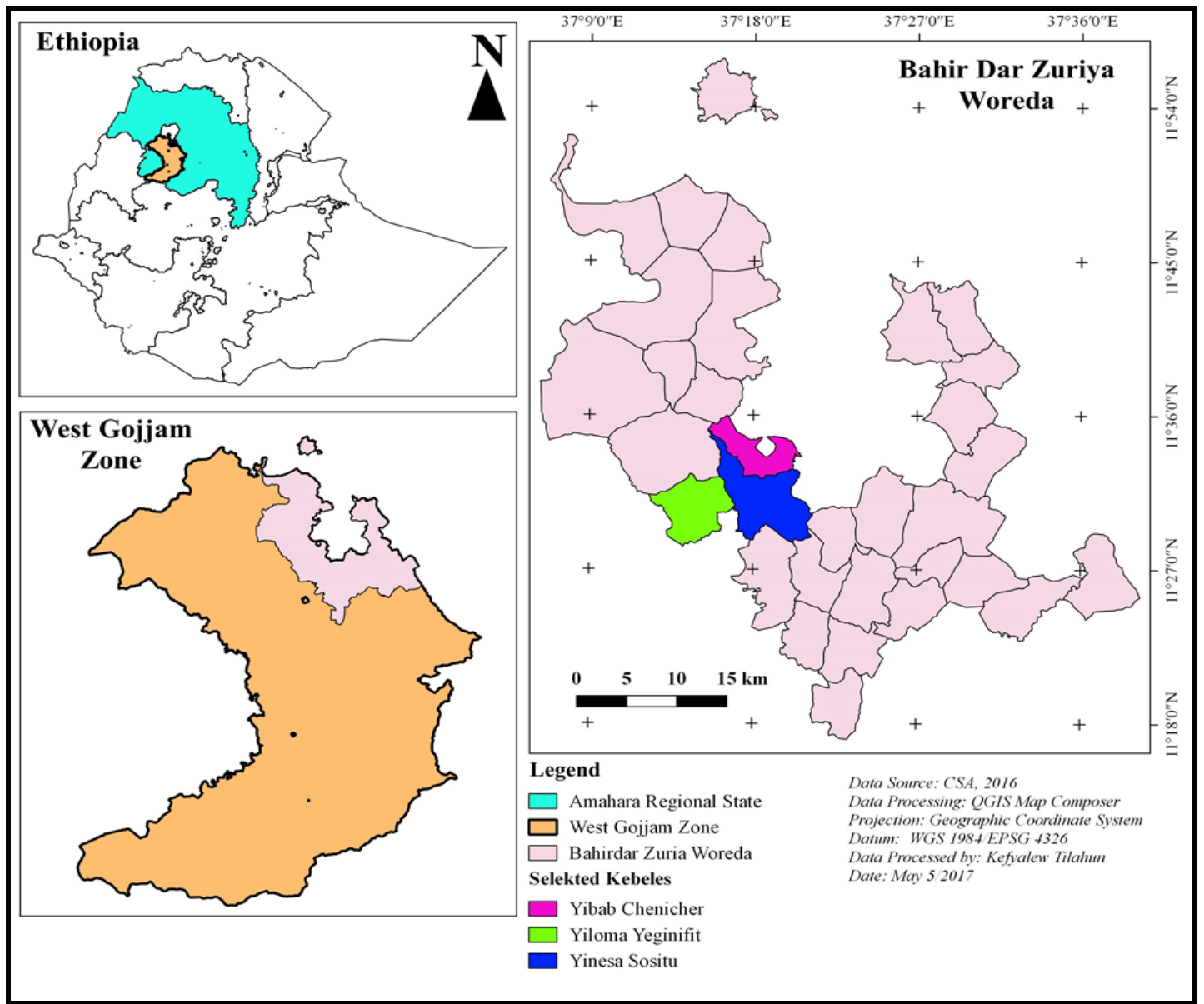

Figure 1; Map of the study area

\subsection{Sampling Techniques}

Multi-stage sampling techniques were employed to select sample kebeles and respondent farmers. In the first stage, from 32 kebele in Bahirdar Zuria woreda, three kebele namely Yinesa Sositu, Yibab Chencher, and Yiloma Yegnfit kebele were selected purposively. The kebele selection criteria were due to relative activities in introduced physical soil and water conservation intervention program and the problem related to lack of maintenance of existing introduced PSWC measure and aggravated soil erosion problem due to lack of practice soil conservation measure on cultivated land were identified by different projects actors and woreda agricultural office. At the second stage, a list of household heads in the selected kebeles was obtained from the Kebele offices and development agents (DAs) to stratify households into user and non-user households for this study. The three Kebeles have a total of 2915 household heads. In the third stage, the probability proportional to size/ population technique was used to fix the number of the sample households selected from each kebeles. Finally, a simple random sampling technique was used to select 132 respondents from user households and non- user of PSWC measure in each kebeles on cultivated land.

Table 1. Distribution of sample household heads in each kebele

\begin{tabular}{lllll}
\hline Sample kebeles & Adopter & Non-adopter \\
\hline Yinesa Sositu kebele & 483 & 22 & 596 & 27 \\
Yibab Chencher kebele & 288 & 13 & 638 & 29 \\
Yiloma Yegnfit Kebele & 369 & 16 & 541 & 25 \\
\hline Total & 1140 & 51 & 1775 & 81 \\
\hline
\end{tabular}

Note: $\mathrm{N}=$ total number of household heads, $\mathrm{n}=$ number of sample household

Source: Own sampling design (2017)

\subsection{Method of Data Collections}

Both qualitative and quantitative data were collected from primary and secondary sources through field observation, structured household interviews, and focused group discussions. Qualitative data were collected from elders, selected farmers, and key informants, who have adequate knowledge and information about the past and present condition of the study area. The knowledge and information from these sources include land use, 
PSWC practices, causes for lack of continued use of existing physical soil and water conservation measures, consequences of soil erosion. The quantitative primary data include household characteristics (age, education, and family size), farm characteristics (source of farm plot, farm size and distance of farm plots from home), institutional factors (training, extension contact, and membership), perception of soil erosion, causes, extents and consequences of soil erosion, type of SWC practices and off-farm activities. Secondary data were compiled through review various literatures of published articles and other scholarly materials conducted in Ethiopia.

\subsection{Methods of Data Analysis}

Qualitative data were analyzed through interpretation and conceptual generalization. For quantitative data, both descriptive statistics and the econometric model were implemented on SPSS 20 software packages and Microsoft Excel version. The descriptive techniques of the analysis were frequency, percentage, and piechart. Practices of physical soil water conservation measures and continued use of existing physical soil and water conservation measures were analyzed descriptively. Mean differences for independent variables were tested using the p-value and chi-square test. With regard to econometric analysis, the logistic regression model was employed to investigate factors affecting the adoption of introduced physical soil and water conservation measures on cultivated land.

\section{RESULTS AND DISCUSSIONS}

\subsection{Introduced physical soil and water conservation measures}

The survey result showed that farmers' in the study area practiced improved physical soil and water conservation measures on cultivated land. Results indicated that (Figure 1) improved soil bund and cut off drains are relatively dominant conservation structures practiced in the area. While stone bund and stone-faced soil bund conservation measures practiced at a low level by smallholder farmers. Focus group discussants and key informant farmers further elaborated that even if it is effective in soil erosion, the limited implementation of stone bund and stonefaced soil bund measures was due to the labor-intensive nature of the structures, technical and maintenance problems. And also stone used for other sources of income in the study area for making foundation in the construction of the house. The result was consistent with the finding of Habtamu (2014), who found that the limited implementation of the stone bund was due to the problem of the availability of larger stones around their farm plots, labor-intensive nature for the construction and maintenance of the structure, and lack of awareness. Similarly, Mazengia and Mowo (2011) indicated the continued use of stone bund SWC structures are challenged by dependency to aid, unwillingness to accept technical re commendations, lack of interest by land users and local leader, and loose partnership with development agent.

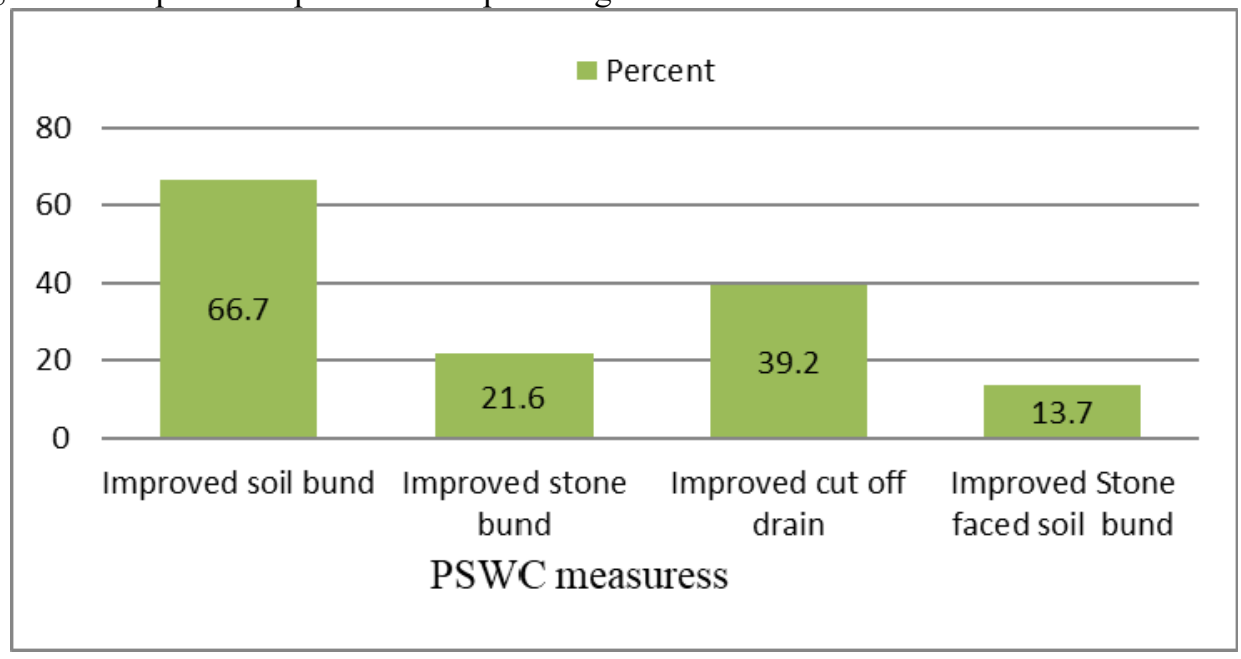

Figure 2: Widely used PSWC measure on cultivated land.

Note that there are multiple responses. Source: Computed from survey data (2017) 

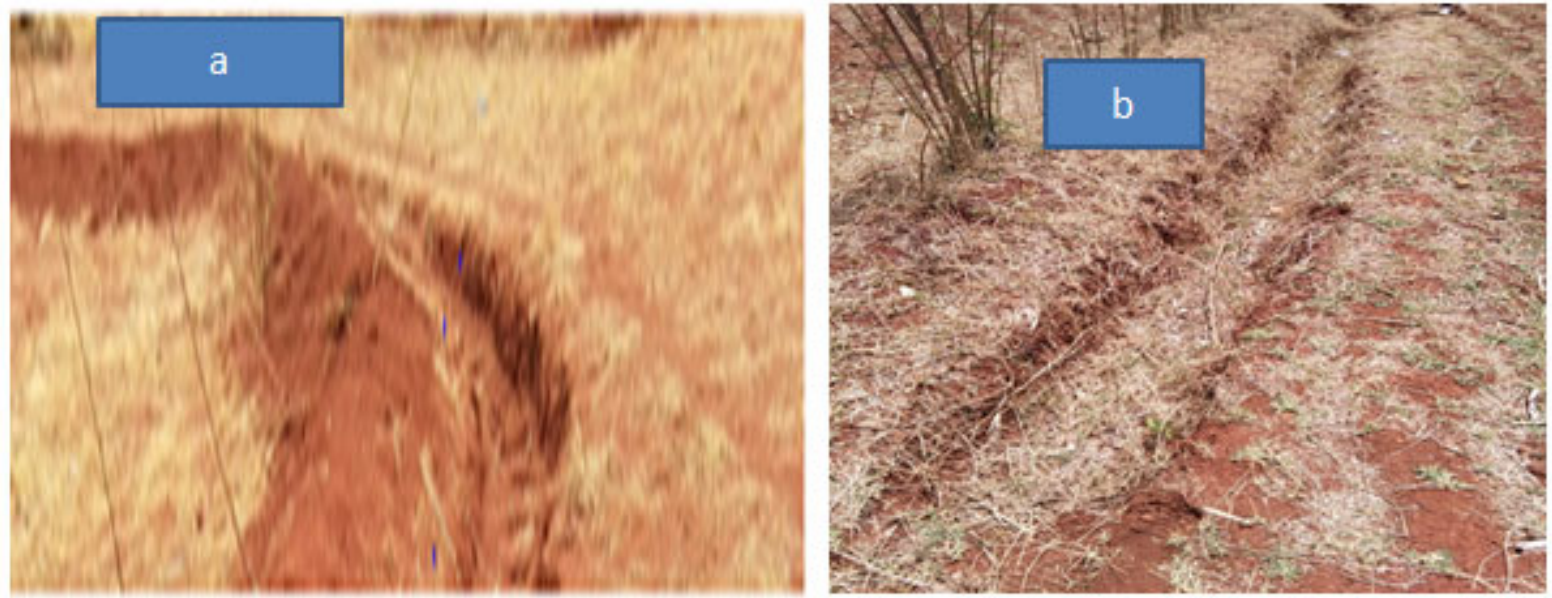

Figure 2. Widely practiced improved soil bund in the three kebeles, a) young and b) old PWC measures.

\subsection{Farmers' Continued use of existing introduced PSWC}

The survey result (figure 2) showed that a farmer's response to the maintenance of the existing PSWC measure was categorized into four parts; reconstructed, retained, partially removed, and totally removed from cultivated land. Results showed that $13.7 \%$ and $29.4 \%$ of respondents have retained and reconstructed physical soil and water conservation measure respectively. In contrast, about $39.2 \%$ of the respondents removed partially, and the remaining $17.6 \%$ of respondents totally removed conservation structures from their cultivated land. The finding was in line with Yeraswork (2000), who indicated that the majority of farmers have been totally or partially removed conservation structures constructed on their cultivated land. This is due to physical soil and water conservation structures need frequent maintenance, which is high labor demanding, loss of land to conservation. .These problems resulted in a negative attitude towards the sustainability of soil and water conservation structures. Similarly, Woldeamlak (2003) reported that more than half of the farmers that installed conservation structures on their cultivated land did not plan to maintain and reconstruct the structures after initially adopt the technology.

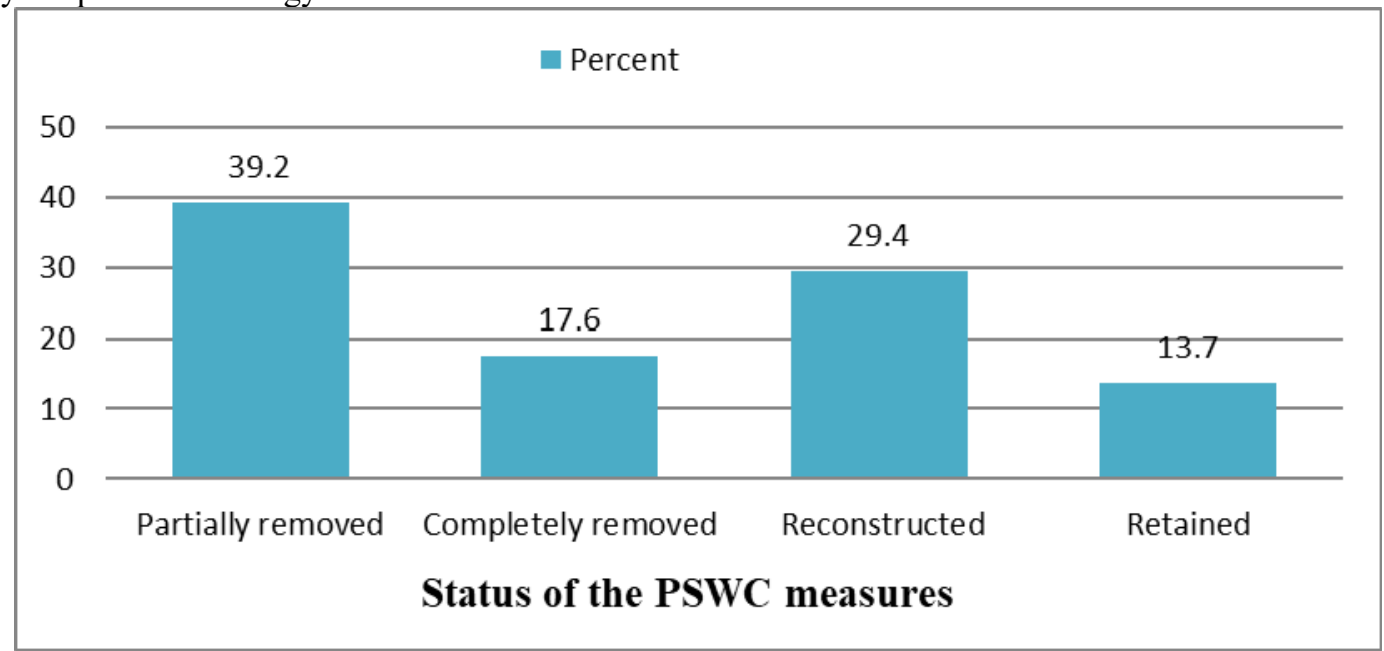

Figure 3: Condition (status) of the existing structure on cultivated land $(\mathrm{n}=51)$

Source: Field survey, 2017

The result also revealed that out of the total user sample household $64.8 \%$ of the respondent were not maintain existing soil conservation structure while $35.2 \%$ maintain the existing structure on cultivated land. This implies that most farmers did not give attention to maintain soil conservation structure even though most farmers perceived the existence and impact of erosion problems on cultivated land. The result supported with the focus group discussion confirmed that lack of maintaining or partially and completely removed the structure was due to difficulty to turn oxen during plowing, lack of intervention measures (follow-up) by woreda and kebeles experts, and loss of land due to construction of the bund. The result is consistent with Legesse (2021), who found that partially and the completely removed structure was due to the lack of farmers' knowledge and skill to adapt land management technologies and lack of intervention measures by government and non-governmental organizations. 


\subsection{Discouraging factors for continued use of PSWC measures and Farmers' perception of soil erosion}

The survey result indicated (Table 1) that different daunting factors were found to continue the use of existing physical soil and water conservation measures. Of which inadequate labor (49\%), loss of land to the bund $(45.1 \%)$, work is very tedious $(33.3 \%)$, rodents and pests hide on the bund (19.6\%), source of land (47.1\%) and few don't believe in the use of PSWC measure $(3.9 \%)$ were the major discouraging factor to smallholder farmers' on cultivated land. Other studies carried out elsewhere have concluded that farmers fail to adopt PSWC technologies, not for lack of concern for sustainable land use but for the inappropriateness of the technologies provided. For instance, in India's semiarid tropics, farmers failed to maintain or even intentionally ruined the introduced PSWC measures because the measures were not suitable for their small farms (Kerr and Sanghi, 1992). The result is contradicted with Kerr and Sanghi (1992) investigation because in the study area the main problem farmers failed to the continued use or ruined the introduced PSWC measures is not because the measures were not suitable for their cultivated land.

Table 2. Factors that daunting farmers' to maintain existing PSWC measure $(n=51)$

\begin{tabular}{ll} 
Discouraging factor to continued use of existing PSWC measures & Percent \\
\hline Inadequate of labour & 49.0 \\
Loss of land to the bund & 45.1 \\
Works is very tedious & 33.3 \\
Rodents and pests hide on the bund & 19.6 \\
Due to source of land (rented land) & 47.1 \\
I don't believe in the use of PSWC measure & 3.9 \\
\hline
\end{tabular}

Note that there are multiple responses

Source: computed from field survey, 2017

In addition, the survey result indicated that farmers classified their cultivated land depending on their perception of the degree of erosion problem (i.e., extent or severity of occurrence of soil erosion on the farm land). The respondents were given three alternatives: low, medium, and high to indicate the severity of the problem. The survey result showed in figure 3, majority of the farmers $(40 \%)$ and $37 \%$ were experienced medium and high soil erosion problem respectively, whereas $23 \%$ of the respondents encountered low soil erosion problems. A Chi-square test indicated that there is a significant relationship between perception of erosion as a problem and adoption of soil and water conservation structures $(\chi 2=18.9, \mathrm{P}=0.074)$.

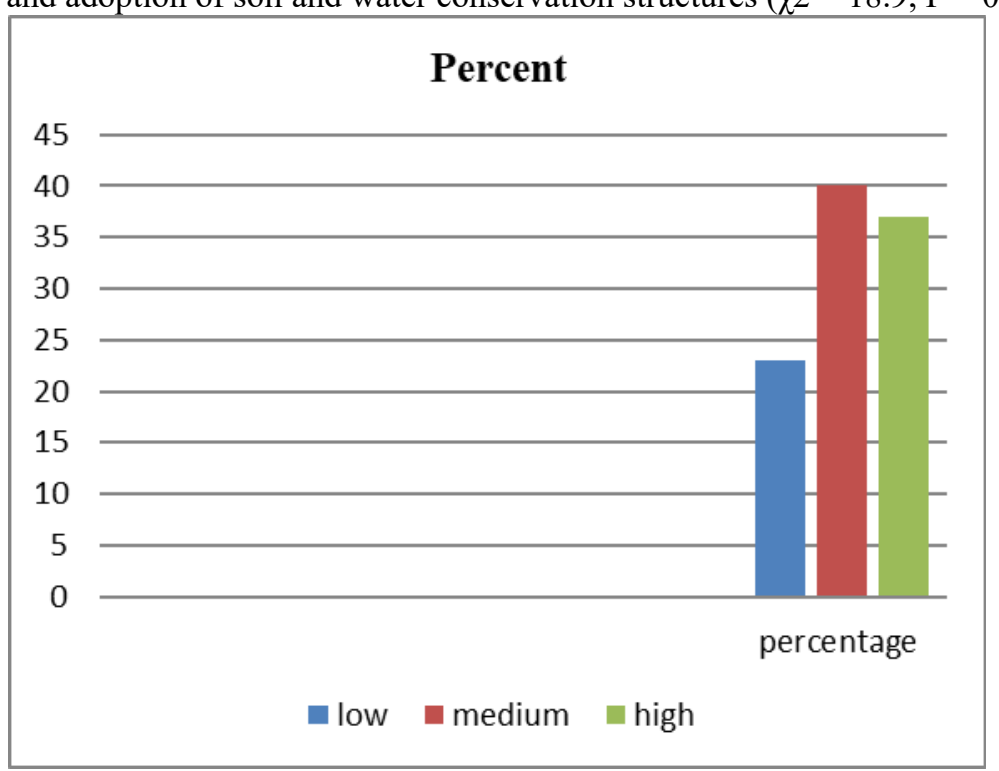

Figure 3: The bar graph showed the farmers perception and soil erosion severity.

According to Morgan (2005), the main agents of soil erosion are water and wind, each contributing a significant influence on the detachment and transport process. Obviously, the role of water in eroding the land is very high during the intensive rainy season while wind causes erosion during the dry windy season. Moreover, among the interviewed smallholder farmers, about $30 \%$ and $29 \%$ ranked heavy rain and over-cultivation as the main causes of soil erosion in the study area respectively (Figure 4). The respondents also indicated the cultivation of steep slope and overgrazing and other factors contributing to soil erosion in the study area. 


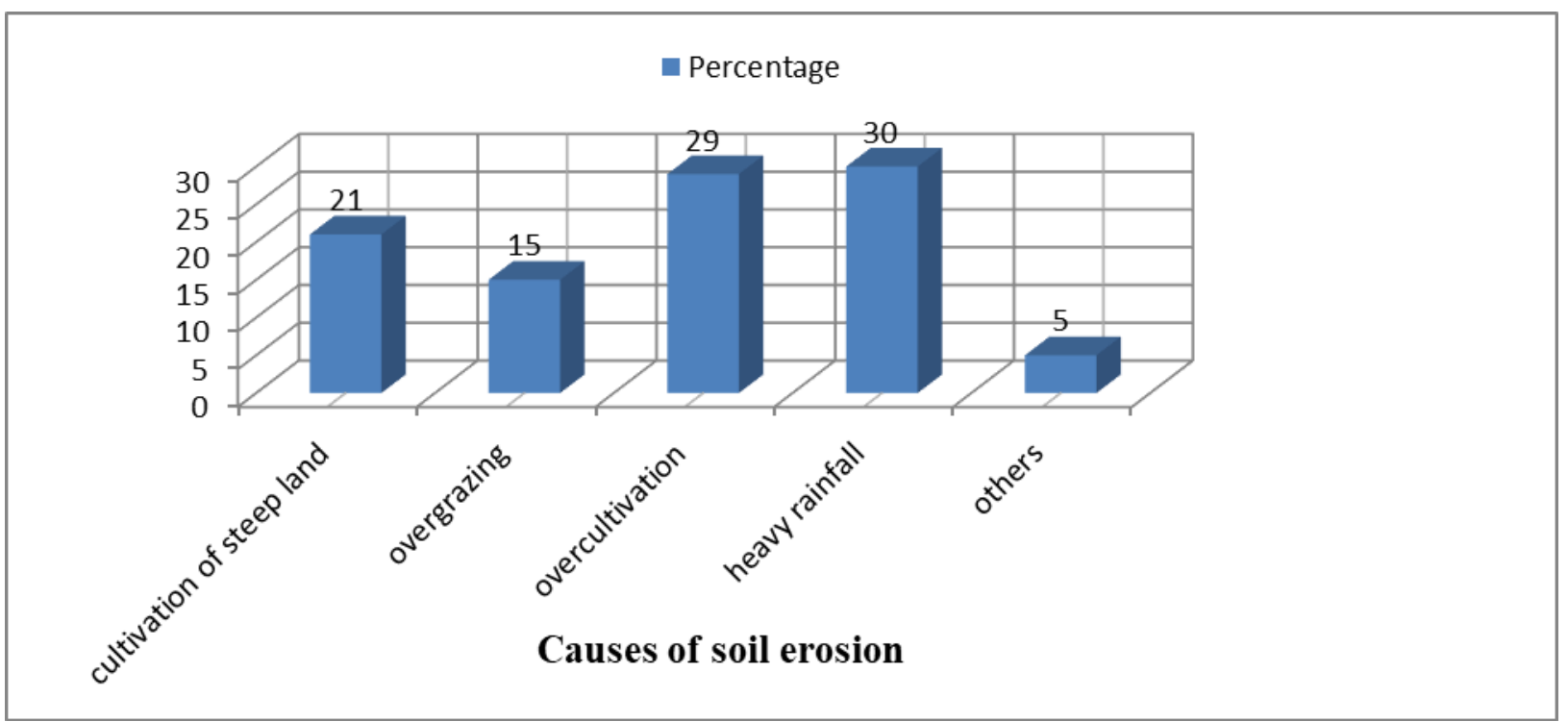

Figure 4: The distribution of farmer's response by perception on causes of soil erosion. Source: Own analysis from survey data, 2017

\subsection{Factors affecting use of improved structural SWC measures}

This result of the binary logistic econometric model analysis conducted to investigate factors affecting the adoption of PSWC measures (Table 3). The dependent variable was the adoption of improved PSWC measures, which run on 132 household respondents. Econometric models estimate not only directions of relationships but also the significance of relationships between dependent and independent variables. This model showed the existence of positive or negative relationships between dependent and independent variables and the amount of influence of independent variables on the dependent variable. The regression analysis was first performed for the three sample kebeles separately. However, except for minor changes in the coefficient $\beta$ the determinant variables turned out to be similar. Therefore, the analysis was done for the whole sample households $(\mathrm{n}=132)$. There were 15 explanatory variables that entered into the binary logistic model. The household characteristics such as education, extension contact, training, perception on soil erosion, perception on the profitability of PSWC, landholding size of the household head did have a significant impact on the adoption and maintenance of PSWC structures in this study (Table 3). Whereas involvement in off-farm activities, membership and distance from the farmland were affected negatively by the adoption and maintenance of PSWC measures.

Table 3. Result of Logistic model for adoption of PSWC measures on cultivated land.

\begin{tabular}{|l|l|l|l|l|l|}
\hline Variables & Coefficient & S.E. & Wald & Sig & Exp(B) \\
\hline OFFARM & -1.502 & 0.521 & 8.318 & $0.004^{* * *}$ & 0.223 \\
\hline AGE & 0.024 & 0.026 & 0.882 & 0.348 & 1.024 \\
\hline TRAIN & 1.766 & 0.564 & 9.794 & $0.002^{* * *}$ & 0.671 \\
\hline EXTENTION & 1.339 & 0.603 & 4.923 & $0.026^{* *}$ & 0.515 \\
\hline POFSF & -0.499 & 0.534 & 0.876 & 0.349 & 0.607 \\
\hline MEMBERSHIP & -1.361 & 0.606 & 5.054 & $0.025^{* *}$ & 0.256 \\
\hline SEX & 0.640 & 0.535 & 9.401 & 0.752 & 5.155 \\
\hline EDUCTION & 1.616 & 0.505 & 1.487 & 0.223 & 1.851 \\
\hline HHSIZE & 0.154 & 0.140 & 1.214 & 0.381 & 1.166 \\
\hline SLOP & 0.688 & 0.560 & 1.507 & 0.220 & 1.990 \\
\hline PROF & 1.570 & 0.530 & 8.774 & $0.003 * * *$ & 4.805 \\
\hline SOURCEOF LAND & -0.174 & 0.512 & 0.115 & 0.734 & 0.840 \\
\hline DISTANC & -0.199 & 0.486 & 0.168 & 0.682 & 0.819 \\
\hline PERERO & 0.736 & 0.541 & 1.851 & $0.074 *$ & 2.087 \\
\hline FRMSIZE & 0.204 & 0.298 & 0.467 & 0.194 & 1.226 \\
\hline Constant & -3.529 & 1.368 & 6.656 & 0.010 & 0.029 \\
\hline
\end{tabular}

-2 Log likelihood $=121.725 \quad \chi 2=15.370 \quad$ R Square $=0.6830$

The result showed that contact with extension agents (EXTENTION) correlates positively $(\mathrm{B}=1.339)$ with the adoption of PSWC measure and significant at a $1 \%$ level of significance. This implies that farmers having contacts with extension agents increase by $51 \%$ (Expected percent) the adoption of soil and water conservation structure and also tend to understand the problem of soil erosion and the benefits of conservation structure and 
they are more likely to use conservation structures. This result contradicts the finding of Aklilu (2006) in the Beressa watershed, highlands of Ethiopia, who reported that discussions with extension staff in the area reveal that agricultural extension is more focused on crops and livestock production than PSWC measure implantation and maintainace of it.

Farmer's perception of the profitability of PSWC measure (PROF) correlates positively with the adoption of PSWC measure and significant at a $1 \%$ level of significance. This implies that farmers who found the PSWC measure profitable in the long run in erosion control and improve productivity through retaining nutrients; they retained and redevelop the existing structure. The result was consistent with the result of Million (2004) who found that farmers' perception of profitability of the conservation structure in erosion control affected farmers' decisions positively.

Farmer's perception of soil erosion problem (PERERO) affects farmers decision to adopt physical soil and water conservation measures positively and significant at $10 \%$ level of significance. The implication of the study that a farmer who feels that his farmlands are exposed to soil erosion is more likely to adopt structural soil and water conservation measures than those who do not perceive the problem of soil erosion. This result is consistent with the finding of (Aberham, 2008; Woldeamlak, 2003 and Eyasu, 2005). Those found that when farmers do not acknowledge soil erosion as a problem, they cannot expect benefits from controlling the erosion process and it is highly likely that they can decide against adopting any conservation structure on cultivated land.

Farmers' participation in off-farm activities (OFFARM) affecting farmers' decision to adopt soil conservation measures negatively and statistically significantly at a $1 \%$ level of significance. The implication of the study was farmers who involve in off-farm income-generating activities were far from the farming land and likely to put less effort into maintenance and hence on retention of conservation structures. The result was consistent with Tenge (2004), who found that the probability use of soil conservation structures decreases with increasing farmer's involvement in off-farm income-generating activities. Similarly, Mekuriaw et al. (2017) reported that off-farm activities (selling firewood) and the use of free grazing systems (communal land) influenced the adoption of introduced SWC practices negatively and it was statistically significant. Farmers who practiced off-farm activities such as pretty trade and selling of firewood were not maintaining PSWC structures because off-farm activities that occur in the dry season when bunds are constructed and maintained.

Participation in training related to PSWC activity (TRAIN) was found positively and significantly influences the adoption of PSWC at a $1 \%$ level of significance. This implies that training about PSWC measures is one of the major sources of information to adopt PSWC. Moreover, taking training widens the household's knowledge with regard to increasing farmers' attributes and practices towards the adoption of physical soil and water conservation by $67 \%$ on cultivated land. The result was consistent with Kebede (2006), who found that training on PSWC activity has a positive influence on the adoption of soil conservation structures.

Unexpectedly membership of the farmer in local organizations (MEMBERSHIP) was found negatively and significantly influence at a 5\% level of significance with the adoption of conservation structures. This was due to involved in membership like farmers involved in local leadership (administration) and off farm activity like kebele organization have no time to put effort on soil conservation use and also mostly focused or discussions on expansion of education facility in village and health service than working on PSWC measure on cultivated land. This result contradicts the finding of Semgalawe (1998) also reported the degree of access the farmer has to information from agricultural experts had a positive influence on conservation decisions of the recommended type and modified types of conservation structure.

The sizes of farmland (FRMSIZE) affect positively the farmers' decision on the adoption of structural soil and water conservation measure. This implies farmers with larger farm size can afford to retain and reconstruct structures compared to those with relatively lower farm size that part of the scarce productive land occupy by conservation structures. Our finding was consistent with the finding of Amsalu and De-Graaff (2007) found that farmers who have large farms are more likely to invest in soil conservation measures. Furthermore, Kebede (2014) revealed that farmers who had larger farms are more likely to apply SWC measures than those whose farms are relatively small.

The variable household plan to continue in farming activity (POFSF) correlates negatively with the adoption of PSWC measures. This implies that households plan to leave farming activity influences farmers 'decision to adopt PSWC measure negatively due to limiting the planning horizon of farmers on cultivated land. This result contradicted with Lee and Stewart (1983), who found a longer planning horizon, tends to encourage conservation decisions by increasing the present value of expected net return and by allowing sufficient time to maintain and retained conservation structure.

\section{CONCLUSION RECOMMENDATION}

Different PSWC measures are practiced on cultivated land by smallholder farmers. Among these improved soil bund, cut off drain are relatively dominant conservation measures practiced in the area. While Stone bund and stone-faced soil bund conservation measures practiced at a low level. The continued use of existing soil and 
water conservation structures through maintaining and retained were varied among households. Even though majority of the smallholder farmers were perceived medium and high soil erosion problem on their cultivated land, majority of the smallholder farmers not maintain the existing structures due to different discouraging factors among these inadequate labours, loss of land to the bund and works is very tedious to smallholder farmers. The result of the study showed that farmers' decision to adopt the introduced PSWC measures was influenced by multiple factors such as demographic, physical, institutional, and economic factors. The profitability of the PWC structure on soil erosion control, extension contact, training, and perception of the household head on soil erosion problems are found to be positive and significant to households' adoption of PSWC measure while off farm and membership are found to influence the adoption of soil conservation structures negatively and significantly. To make the use and maintenance of PSWC measure sustainable, the Woreda Agricultural officials should give due attention to regular follow-up, delivering training, and encouraging farmers who have a better performance in using and maintaining existing PSWC measures. Considering the essence of these factors might contribute to designing appropriate strategies to attain approach and technical change in sustainable natural resource conservation process in the study area under similar conditions. Furthermore, awareness creation work should be done to enable farmers allocating their time and labor force for the maintenance of soil conservation besides to other off-farm activities. Further research should be conducted on the effectiveness of introduced physical soil and water conservation-related to soil fertility improvement in the district.

\section{References}

Aberham, E. T., (2008). Erosion and soil and water conservation group and environmental Policy group. Continue use of SWC.A Case Study in Tulla District, Ethiopia. Dissertation for Award of MSc Degree at Wagenigen University, 57pp.

Ademe, Y., Kebede, T., Mullatu, A. and Shafi, T., (2017). Evaluation of the effectiveness of soil and water conservation practices on improving selected soil properties in Wonago district, Southern Ethiopia. Journal of Soil Science and Environmental Management, 8(3), pp.70-79.

Adimassu Z, Mekonnen K, Yirga C, Kessler A (2014). Effect of soil bunds on runoff, soil and nutrient losses, and crop yield in the central highlands of Ethiopia. Land Degrad Dev 25(6):554-564.

Aklilu, A. (2006). Caring for the Land: Best Practices in Soil and Water Conservation in

Amare T, Birru Y, Hans H (2013). Effects of "Guie" on soil organic carbon and other soil properties: a traditional soil fertility management practice in the central highlands of Ethiopia. J Agric Sci 5:237-244.

Amede, T., Belachew, T. and Geta, E., (2001). Reversing degradation of arable lands in southern Ethiopia. Managing African Soils, (23).

Amsalu, A. and De Graaff, J., (2007). Determinants of adoption and continued use of stone terraces for soil and water conservation in an Ethiopian highland watershed. Ecological economics, 61(2), pp.294-302

Angima, S. D., D.E. Stott, M.K. O'Neill, C.K. Ong, and G.A. Weesies, (2003). Soil Erosion

Astatike, A.A., (2016). Assessing the Impact of Small-Scale Irrigation Schemes on Household Income in Bahir Dar Zuria Woreda, Ethiopia. Journal of Economics and Sustainable Development, 7(21), p.20167.

Bekele, S and Holden.S., (1999). Resource Degradation and Adoption of Land Conservation technologies in the Ethiopian Highlands: A Case Study in Andit Tid, North Shewa. Agri. Econ., 18(3): 233-247.

Bekele, W. and Drake, L., (2000). Soil and water conservation decision behavior of subsistence farmers in the Eastern Highlands of Ethiopia: a case study of the Hunde-Lafto area. Ecological economics, 46(3), pp.437451.

Belay T., 1992. Farmers' Perception of Erosion Hazards and Attitudes towards Soil Conservation in Gunono, Wolayita, Southern Ethiopia. Ethiopian Journal of Development Research 14, no. 2: 31-58. Beressa Watershed, Highlands of Ethiopia [Doctoral Thesis]; p.149.

De Graaff, J., C. J. Ritsema and L. Stroosnijder, (2009). Land Degradation and Development. Wagningen University, Environmental Service Group. 18p.

Desta, G .G (2010). "Conceptualizing rill erosion as a tool for planning and evaluating soil conservation in Angereb watershed, Ethiopia - Methodological Development: Research Report for Q505 project supported by Eastern and Southern Africa Partnership Program Dev., 21: 184-191.

Ejegue KT (2021). Cause and cost of onsite nutrient loss replacement in the highlands of Ethiopia and implication of SWC measures. J Agric Sc Food Technol 7(1): 154-163. DOI: https://dx.doi.org/10.17352/2455-815X.000103

Erkossa, T., Wudneh, A., Desalegn, B. and Taye, G., (2015). Linking soil erosion to on-site financial cost: lessons from watersheds in the Blue Nile basin. Solid Earth, 6(2), p.765.

Eyasu, E., 2005. Farmer's Perceptions of Soil Fertility Changes and Management. Institute

Fentahun, M.T. and Hager, H., (2009). Exploiting locally available resources for food and nutritional security enhancement: wild fruits diversity, potential and state of exploitation in the Amhara region of 
Ethiopia. Food security, 1(2), pp.207-219.

Gete Zeleke and H. Hurni, (2001). Gete Zeleke and H. Hurni, 2001. Implication of land use and land cover dynamics for mountain resource degradation in the northwestern Ethiopian highlands. Mountain Res. Dev., 21: 184-191.

Habtamu, A., Heluf, G., Bobe, B. and Enyew, A., (2014). Fertility status of soils under different land uses at Wujiraba Watershed, North-Western Highlands of Ethiopia. Agriculture, Forestry and Fisheries, 3(5), pp.410-419.

Haileselassie A, Priess JA, Veldkamp E, Teketay D, Lesschen JP (2005). Assessment of soil nutrient depletion and its spatial variability on smallholders' mixed farming systems in Ethiopia using partial versus full nutrient balances. Agriculture, Ecosyst. Environ. 108:1-16

Haregeweyn N, Ademnur B, Atsushi T, Mitsuru T, Derege TM (2012). Integrated watershed management as an effective approach to curb land degradation: a case study of the Enabered watershed in northern Ethiopia. Environ Manag 50:1219-1233

Haregeweyn, N., Tsunekawa, A., Poesen, J., Tsubo, M., Meshesha, D.T., Nyssen, J, Adgo, E. (2017) Comprehensive assessment of soil erosion risk for better land use planning in river basins: case study of the upper Blue Nile River. Sci Total Environ. 574:95-108

Kebede Manjur, 2006. Farmers' Perception and Determinants of Land Management Practices in Ofla Woreda, Southern Tigray, Ethiopia.An unpublished M.Sc. Thesis Haramaya University, Ethiopia.

Kebede, Wolka. (2014). Effect of Soil and Water Conservation Measures and Challenges for its Adoption: Ethiopia in Focus. Journal of Environmental Science and Technology. 7. 185-199. 10.3923/jest.2014.185.199.

Kerr, J., Sanghi, N.K.., (1992). Indigenous soil and water conservation in India's semi-arid tropics. Gatekeeper series 34. IIED, London, UK.

Kiros, G., Haile, M. and Gebresamuel, G., (2014). Assessing the input and output flows and nutrients balance analysis at catchment level in Northern Ethiopia.Journal of Soil Science and Environmental Management, 5(1), pp.1-12.

Laekemariam., Kibebew K., Tekalign M., and Heluf G. (2016) Soil-Plant Nutrient Status and their Relations in Maize-Growing Fields of Wolaita Zone, Southern Ethiopia, Communications in Soil Science and Plant Analysis, 47:11, 1343-1356,

Lee, L.K. and Stewart, W.H., (1983). Landownership and the adoption of minimum tillage. American Journal of Agricultural Economics, 65(2), pp.256-264.

Legesse, W., Haji, J., Ketema, M. and Emana, B., (2021). Determinants of adoption of sustainable land management practice choices among smallholder farmers in Abay Basin of Oromia, Ethiopia. Journal of Development and Agricultural Economics, 13(1), pp.1-9.

Mazengia, W. and Mowo, J., (2011). Role of collective actions in integrated soil and water conservation: The Case of Gununo Watershed, Southern Ethiopia. Journal of Development and Agricultural Economics, 4(1), 23-36.

Mekonnen Getahun (2015). Characterization of agricultural soils in CASCAPE intervention woredas of Amhara region. CASCAPE report. Bahir Dar University, Ethiopia.

Mekuriaw, A., Heinimann, A., Zeleke, G. and Hurni, H., (2017). Factors influencing the adoption of physical soil and water conservation practices in the Ethiopian highlands. International soil and water conservation research, 6(1), pp.23-30.

Menale, K, J., Pender, Mahmud, Y. G., Kohlin, R. Bluffstone and Elias, M., (2008). Impact of Soil Conservation on Crop Production in the Northern Ethiopian Highlands. International Food Policy Research Institute (IFPRI), USA. 44p.

Million, T. and Belay, K., (2004). Factors Influencing Adoption of Soil Conservation Measures in mountain resource degradation in the northwestern Ethiopian highlands. Mountain Res.

Morgan, R.P.C.2005. Soil Erosion and Conversation. (3 ${ }^{\text {rd }}$ ed.). Black well publishing, Australia.

Semgalawe ZM. (1998). Household Adoption Behavior and Agriculture Sustainability in the Northern Mountains of Tanzania. The Case of Soil Conservation in the North Pare and West Usambara Mountains. $\mathrm{PhD}$ thesis, Wageningen Agricultural University: The Netherlands.

Shimeles D (2012). Effectiveness of soil and water conservation measures for land Restoration in the Wello area, northern Ethiopian highlands. Ecology and Development Series. No. 89.

Slegers, M.F. (2008). "If only it would rain": Farmers' perceptions of rainfall and drought in semi-arid central Tanzania. Journal of Arid Environments, 72(11), pp.2106-2123. Sustainable Development. Addis Ababa, Ethiopia.

Tassew, A. and Seifu, E., (2009). Smallholder dairy production system and emergence of dairy cooperatives in Bahir Dar Zuria and Mecha Woredas, Northwestern Ethiopia. World Journal of Dairy \& Food Sciences, 4(2), pp.185-192. 
Tenge, A., de Graaff, J. and Hella, J. P. (2004). Social and economic factors affecting the adoption of soil and water conservation in West Usambara Highlands. Tanzania. . Journal of Land Degradation and Development 15(2): $99-114$.

Tesfahun,F. and Osman ,A.,(2003). Challenge and prospects of Food security in Ethiopia. Proceeding of the Food Security Conference 2003. UNNCC, Addis Ababa, August13-15, 2003

USAID (United States Agency for International Development). (2000).Amhara National Regional State food security research assessment report, Available at: http://crsps.org/amhara/amhara_rpt.PDF: Impacts, factors and control. 132153

Van Beek, C.L., Elias, E., Yihenew, G.S., Heesmans, H., Tsegaye, A., Feyisa, H., Tolla, M., Melmuye, M., Gebremeskel, Y. and Mengist, S., (2016). Soil nutrient balances under diverse agro-ecological settings in Ethiopia. Nutrient Cycling in Agroecosystems, 106(3), pp.257-274.

Wegayehu, B., (2006). Economics of soil and water conservation: theory and empirical application to subsistence farming in the eastern Ethiopian highlands, Swedish University of Agricultural Sciences.

Woldeamlak. and Drake, L., (2003). Soil and water conservation decision behavior of subsistence farmers in the Eastern Highlands of Ethiopia: a case study of the Hunde-Lafto area. Ecological economics, 46(3), pp.437451.

Yeraswork, A., (2000). Twenty Years to Nowhere: Property Rights, Land Management and Conservation in Ethiopia. Asmaru: the Red see press.

Yirga C. (2007). The dynamics of soil degradation and incentives for optimal management in the Central Highlands of Ethiopia (Doctoral dissertation, university Pretoria). 